\title{
企業合理化に伴う企業城下町の中心商業地の変容 兵庫県相生市を事例として
}

\author{
難波田隆雄（財団法人水島地域環境再生財団）
}

\begin{abstract}
本研究では, 企業城下町相生市を事例に, 企業合理化に伴う中心商業地の変容を明らかにするため, 店舗 交替の経年的変化と非商店の実態から非商店化の過程と要因を解明した. 相生市では合理化以降, 商業の衰 退が深刻である. 中心商業地は, 企業が設置した売店組合を基盤に, 戦後企業の発展ととあに成長したが, 近年では人口や歩行者通行量が著しく減少し, 非商店化している. バブル崩壊以前は店舗交替が進展してい たが，崩壊後は新規出店が少なく，店舗閉鎖が非商店化につながっている．中には住民の存在，所有者の意 向により店舗交替を阻害している区画あ含まれるが, 賃貸可能性のある空き店舗む多い. これらから, 合理 化により衰退しつつあった中心商業地において, バブル崩壊以降, 新規参入需要が低下したことが非商店化 の主たる要因であるといえる，したがって，企業城下町の中心商業地における非商店化は，最盛期の規模 · エリアの縮小を示している.

キーワード：空き店舗, 中心商業地, 企業城下町, 企業合理化, 兵庫県相生市
\end{abstract}

\section{I はじめに}

地方都市において, 中心商業地の空洞化が問題と なって久しい. 空洞化の進展状況は, 都市の人口規 模, 周辺環境などにより大きく異なり, 全国的に一 様ではない，近年, 空洞化問題が深刻化し, 対応が 迫られるようになっているのは，中心商業地におい て空き店舗の発生や大型店の撤退などが後を絶たな いからにほかならない。

都市構造の解明を試みてきた地理学の分野におい ては,こうした課題に対して関心が高く, 多数の研 究が蓄積されている。 戸所（1991）は，人口規模や 性格の異なる複数の都市を事例に, 中心商業地の変 容や大型店の立地動向から都市の商業構造の変容を 解明している.ささに，消費者の購買行動の変化に ついても分析を加え, 商業の近代化の方向性を示し ている. 杉村（1998）む，複数の都市を取り上げ, 中心商業地の変容を大型店の出店状況, 昼夜間人口, 步行者通行量, 路線価格の推移, 業種構成の変化な どから明らかにしている。根田（1999）は，1980 年代における地方都市における小売業の空間構造と
その変化を解明している.

また, 地方都市において, 中心商業地の空洞化が 深刻化している現在では, 空洞化のプロセスや要因, 空洞化に伴う中心商業地の变容を分析している研究 が蓄積されている．石澤（1999）や千葉（1999）は, 中心商店街の空洞化のプロセスを，郊外商業地や駅 前商業地への大型店の立地動向から説明している. 五十嵐（1996）や川田（1999）は，周辺環境の変化 だけでなく, 中心商店街の構成店舗の状況，さらに は経営者の意識を取り上げ，その分化を明確にして いる．兼子ほか（2002）は，中心商業地の変容や空 洞化のプロセスや要因を解明するだけでなく，地域 で取り組まれてきた振興策や担い手のあり方に評価 を加えている．林（2001）は，中心商店街の空き店 舗の分布と活用事例を示すとともに，空き店舗の土 地建物所有関係之賃借の可能性を明らかにしている.

いずれの研究も, 詳細な地域調査に基づき, 大型 店の立地動向や中心商業地の構成店舗の状況や経営 者の意識などから空洞化に伴う中心商業地の変容を 解明している，これらは，中心商業地の活性化を考 える上で, 貴重な成果であるといえる. 
しかし，中心商業地の空洞化問題を都市の産業動 向之関連付けて解明している研究は, ほとんどみら れない. 特に, 人口規模の小さい都市や企業城下町 では, 産業動向が都市の商業構造に及ぼす影響が強 い. そのため, これらの都市において, 中心商業地 の変容を解明するためには, 産業動向からのアプロ 一チあ必要となってくる.

さらに, 中心商業地の変容について, 既往研究で は土地利用や業種構成の変化から明らかにされてき たが，非商店 1）化の過程と要因が必ずしも明らか にされているとはいえない，特に，空き店舗につい ては, その分布, 数, 率の変化が取り上げられてき ただけであり, 中心商業地の衰退の程度を示す指標 として扱われてきたにすぎない.

非商店化とは, 店舗の閉鎖後, 新規出店がみられ ず，店舗として活用されていない状態（空き店舗, 倉庫，住宅 ${ }^{2)}$, 駐車場）に変化することである。つ まり, 商店街に抢ける非商店化とは, 店舗交替が進 展せずに，店舗の閉鎖が新規出店を上回っている状 況であるといえる. したがって, 非商店化の過程と 要因を明らかにするためには，店埔の閉鎖要因を解 明するだけでなく，店舗交替の経年的変化を分析し， さらに店舗交替を阻害する要因を解明しなくてはな らない.

そこで, 本研究では, 人口 34,318 人 (2000 年国 勢調查) の企業城下町兵庫県相生市を対象に, 都市 の産業動向と関連付けて中心商業地の変容を明らか にするととあに, 店舗交替の経年的変化と非商店の 実態から非商店化の過程と要因を解明する。 そのた めに，まずII では，相生市の概要と商業環境を主 として統計分析に基づいて明らかにする. 次に, III では中心商業地の変容を明らかにするために，2 時点間の土地利用図を作成し，それらを比較する. さらに, 中心商店街の土地利用形態を経年的に整理 し，店舗交替の変化を明らかにする，IVでは，聞 取り調查3)により明らかになった非商店化以前の
店舗の経営形態，店舗閉鎖の形態ならびに理由，居 住者の有無, 土地建物所有関係などを分析し非商店 化の実態を解明する，最後に，Vでは本研究の結 果をまとめることにする.

\section{II＼cjkstart相生市を取り巻く状況}

\section{1. 相生市の概要之産業動向}

図 1 に示したように, 相生市は, 瀬戸内海に面し, 兵庫県の西播磨地域に位置している。相生市は, 2 市 4 町に囲まれており，地方中核都市である姫路市 に近い. 市の中央部を国道 2 号線・山陽自動車道が 東西に，湾岸沿いに国道 250 号線が走っている.さ らに, JR 相生駅は山陽本線・赤穂線と山陽新幹線 の停車駅であり，相生市は西播磨地域における交通 の要衝であるといえる.

また，相生市は，かつて典型的な企業城下町とし て, 早くから造船業を中心に発展を遂げてきた都市 である，特に，高度経済成長期には, 相生市は主要 企業であった石川島播磨重工（以下，IHI）と関連 企業に 10,000 人を超える就労者を吸収し，1962 年 から 1964 年まで単一工場として船舶建造量が世界 一であるなど造船業の好況に支えられ大いに活気を みせていた（相生商工会議所 1997：1-10）。そのた め, 人口は 1975 年にピークに達し, 42,988 人とな った（1975 年国勢調查）。

しかし, 造船業は 2 度のオイルショックにより構 造不況業種へ転落し, さらに 1980 年代以降は急激 な円高により競争力が低下した。このため, 1986 年に IHI は設備を $60 \%$, 従業員を約 7,000 人削減 する合理化を行った。相生市においては，80 年間 に渡る歴史と伝統を誇った造船部門が全面休止され た（相生市史編纂専門委員会 1989：894-895).

IHI の合理化に伴い, 相生事業所では 2,537 人が 離職した。 そのうち, 233 人は会社側の斡旋により 就職, 87 人は県外に転出した. 残りの 2,217 人が 相生市ほか県内の公共職業安定所に求職を申し込ん 


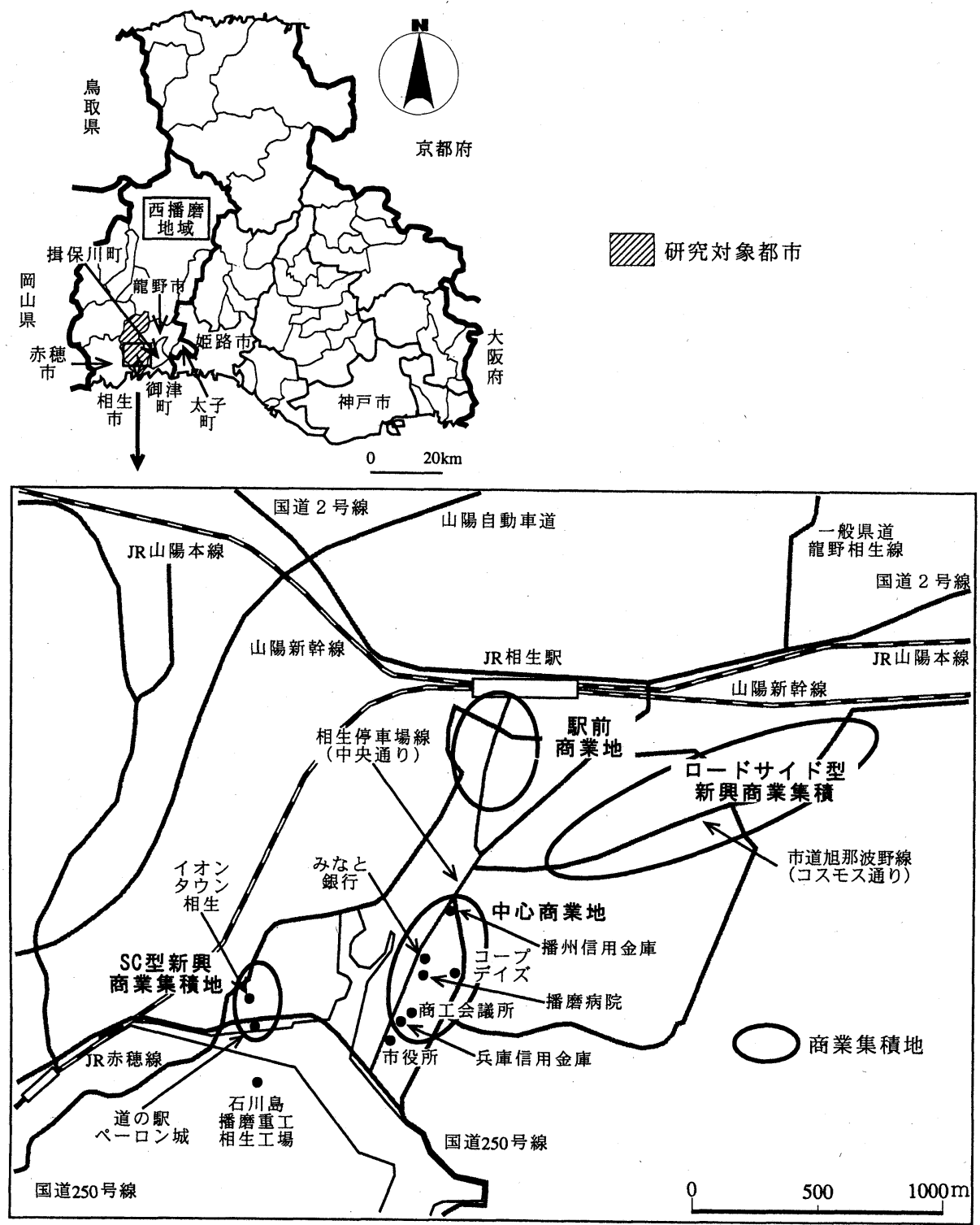

図 1 研究対象地域

Fig. 1 Study area

だが，再就職率は 79.3\%（1989 年）であった（国 立国会図書館調査立法考查局 1990：62-63).

合理化が行われた 1986 年から 1989 年にかけての 人口減少率は, 約 $5 \%$ であり, それほど大きくなか った（国立国会図書館調查立法考查局 1990：136）. しかし, その後, 相生市は産業構造を転換すること
ができず，人口は減少の一途をたどることになった。 ピークであった 1975 年と比較すると, 2000 年の人 口は, $20.2 \%$ 減少し, 34,318 人（国勢調査）とな っている. 
表 1 相生市ならびに近隣市・兵庫県における商業の動向 Table 1 Trends in commerce in Aioi, neighboring cities, and Hyogo Prefecture

\begin{tabular}{|c|c|c|c|c|c|}
\hline & & & 1982 & 1991 & 2002 \\
\hline \multirow{7}{*}{ 相生市 } & \multirow{2}{*}{ 商店数 } & (店) & 596 & 506 & 349 \\
\hline & & 増減率 (\%) & 100.0 & 84.9 & 58.6 \\
\hline & \multirow{2}{*}{ 年間販売額 } & （億円） & 330 & 383 & 279 \\
\hline & & 増減率 (\%) & 100.0 & 116.1 & 84.5 \\
\hline & \multirow{2}{*}{ 売場面積 } & $\left(\mathrm{m}^{2}\right)$ & 34,188 & 32,894 & 30,124 \\
\hline & & 増減率 (\%) & 100.0 & 96.2 & 88. 1 \\
\hline & \multicolumn{2}{|c|}{ 小売吸引比率 } & 1.0 & 0.9 & 0.8 \\
\hline \multirow{7}{*}{ 姫路市 } & \multirow{2}{*}{ 商店数 } & (店) & 7,412 & 7,138 & 6,613 \\
\hline & & 増減率 (\%) & 100.0 & 96.3 & 89.2 \\
\hline & \multirow{2}{*}{ 年間販売額 } & （億円） & 4,245 & 6,451 & 5,807 \\
\hline & & 増減率 (\%) & 100.0 & 152.0 & 136.8 \\
\hline & \multirow{2}{*}{ 売場面積 } & $\left(\mathrm{m}^{2}\right)$ & 442,388 & 535,292 & 628,473 \\
\hline & & 増減率 (\%) & 100.0 & 121.0 & 142.1 \\
\hline & \multicolumn{2}{|c|}{ 小売吸引比率 } & 1.2 & 1.3 & 1.2 \\
\hline \multirow{7}{*}{ 龍野市 } & \multirow{2}{*}{ 商店数 } & （店） & 679 & 615 & 507 \\
\hline & & 増減率 (\%) & 100.0 & 90.6 & 74.7 \\
\hline & \multirow{2}{*}{ 年間販売額 } & （億円） & 377 & 506 & 513 \\
\hline & & 増減率 (\%) & 100.0 & 134.4 & 136.3 \\
\hline & \multirow{2}{*}{ 売場面積 } & $\left(\mathrm{m}^{2}\right)$ & 44,673 & 54,197 & 70,659 \\
\hline & & 増減率 (\%) & 100.0 & 121.3 & 158.2 \\
\hline & \multicolumn{2}{|c|}{ 小売吸引比率 } & 1.2 & 1.1 & 1.3 \\
\hline \multirow{7}{*}{ 赤穂市 } & \multirow{2}{*}{ 商店数 } & （店） & 824 & 775 & 586 \\
\hline & & 増減率 (\%) & 100.0 & 94.1 & 71.1 \\
\hline & \multirow{2}{*}{ 年間販売額 } & （億円） & 386 & 528 & 515 \\
\hline & & 増減率 (\%) & 100.0 & 136.8 & 133.4 \\
\hline & \multirow{2}{*}{ 売場面積 } & $\left(\mathrm{m}^{2}\right)$ & 43,706 & 51,909 & 80,119 \\
\hline & & 増減率 (\%) & 100.0 & 118.8 & 183.3 \\
\hline & \multicolumn{2}{|c|}{ 小売吸引比率 } & 1.0 & 0.9 & 1.0 \\
\hline \multirow{6}{*}{ 県計 } & \multirow{2}{*}{ 商店数 } & (店) & 75,383 & 70,040 & 55,505 \\
\hline & & 増減率 (\%) & 100.0 & 92.9 & 73: 6 \\
\hline & \multirow{2}{*}{ 年間販売額 } & （億円） & 39,299 & 59,736 & 55,063 \\
\hline & & 増減率 (\%) & 100.0 & 152.0 & 140.1 \\
\hline & \multirow{2}{*}{ 売場面積 } & $\left(\mathrm{m}^{2}\right)$ & $3,796,292$ & $4,507,925$ & $5,636,026$ \\
\hline & & 増減率 (\%) & 100.0 & 118.7 & 148.5 \\
\hline
\end{tabular}

小売吸引比率 $=1$ 人当たり販売額 (当該市町村) $/ 1$ 人当たり販売額 (県)

人口には, 1980 年, 1990 年, 2000 年の国勢調査のデー夕を用いた. (商業統計表第 3 巻産業編（市区町村表）各年版により作成).

\section{2. 相生市の商業環境}

まず，相生市の商業集積地について明らかにする。 相生市には四つの商業集積地が存在する（図 1).

中心商業地は，相生駅と IHI の工場とを結ぶ直線 上に位置している，ここには，中心商店街や大型店 が立地し，金融機関や公共機関も集中している.

駅前商業地は, JR 相生駅の南側に展開している. ここには，駅前という立地条件にもかかわらず，商 業機能や業務機能の集積はあまり進んでいない，そ れは，駅前広場等の整備が遅れたため，スペースが きわめて狭隘であるためである.

近年, この二つの商業集積地に, 新たに二つの商 業集積地が加わった。一つは, 1986 年に完成した 「市道旭那波野線（通称コスモス通り）」に展開され たロードサイド型の商業集積地である．各店埔は， モータリゼーションの進展に対応するため, 駐車場 を併設している. あう一つは, 国道 250 号線沿いに 展開している大型ショッピングセンターを核とする 商業集積地である. 以前, ここは広大な遊休地 $\left(35,486 \mathrm{~m}^{2}\right)$ であったが, 2002 年 7 月に「マック スバリュ」と「ディック」を核にした大型ショッピ ングセンターが開店した。 大型ショッピングセンタ 一は，640 台収容可能な駐車場を併設し，13 店舗で 構成される.（マックスバリュ西日本株式会社 2002)。さらに，ここには 1997 年に開店し， 2002 年 4 月に道の駅に認定された「あいおいペーロン 城」が立地している.

次に, 近年の相生市の商業環境について, 近隣市 ならびに兵庫県全体と比較しながら明らかにする。 相生市では, 商店数, 売場面積ともに大きく減少し ており，その傾向に歯止めがかからない状況である （表 1)．そのため，相生市では小売吸引比率む低下 し, 商圏の縮小, 市外への顧客の流出が考えられる。 さらに, 年間販売額の増減率屯, 近隣市, さらには 県全体を大きく下回っており, 商業の衰退が深刻で あるといえる，特に，相生市では 1991 年から 2002 
年にかけて, 商店数ならびに年間販売額の減少が著 しい. しかし，近隣市や県全体と比較すると，相生 市では 1982 年から 1991 年にかけても, 商店数の減 少率は大きく，年間販売額の伸びあ低調である。こ れは，1986 年の IHI 合理化，その後の人口減少が 相生市の商業に大きな影響を与えたためである. 1990 年代以降も人口減少に歯止めがかからず，バ ブル経済の崩壊, 市外への顧客の流出などの影響を 受け, さらに相生市の商業は衰退したととらえるこ とができる.

\section{III 中心商業地の内部構造の変容}

1. 中心商業地の土地利用の变化

1） 1984 年の土地利用

図 2 に, 1984 年の中心商業地の土地利用を示し た.これは，1986 年の IHI 合理化の影響を受ける 直前である．ここでは, 各中心商店街の成立と特徵 を示しながら，土地利用の状況を明らかにする。

まず，本町商店街であるが，これは中心商業地で 唯一アーケードが設置されている幅 $6 \mathrm{~m}$ の歩行者 専用道路に面する商店街である。ここには，振興組 合が組織されており, 本町商店街は中心商業地にお いて唯一法人格を有する商店街である.

本町商店街は 1918 年に発足したが，それは計画 的なあのであった，当時，相生市では第一次世界大 戦による造船ブームにより，労㗢者ならびにその家 族の流入がみられた。 そこで, 播磨船渠株式会 社 4）（現 IHI）は，労働者とその家族のために社員 住宅を建設し，その中心に売店組合を設立した。 売 店組合は，テナントを募集し，2 階建て 6 棟 80 店 舗で開業した，戦後，売店組合の各店舗は分譲され， 本町商店街の基盤が確立された（相生商工会議所 1997: 5).

1960 年に, 本町商店街は協同組合として組織化 されたが，それ以降積極的に近代化に取り組んでき た. 1961 年にアーケードの整備が, 1979 年にカラ
一舗装の整備が行われた。本町商店街では, 1963 年に協同組合から振興組合に組織变更が行われた （相生市史編纂専門委員会 1989：914）。

本町商店街の特徴としては, 他の二つの中心商店 街に比へ，明確な区画がなされ，店舗密度が比較的 高いことが挙げられる(図 2)。店舗密度は店舗数 を商店街の総敷地区画数で除したものであるが，本 町商店街のそれは $85.9 \%$ であった。一方, 空き店 舗や空地や住宅は少なく, 駐車場はみられなかった。 また, 売場面積は大きく 3 種類 (約 $65 \mathrm{~m}^{2}$, 約 $130 \mathrm{~m}^{2}$, 約 $\left.200 \mathrm{~m}^{2}\right)$ に大別されるが，それは売店組合の各 店舗が分譲される際に, 各経営者が必要な売場面積 を確保するために, 1 店舗分, 2 店舗分, 3 店舗分 という形で購入したためである.

本町商店街の 1984 年の店舗構成をみると, 小売

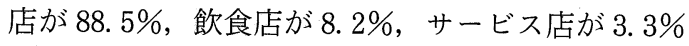
であった. 小売店のうち, 買回品店の割合が高く, それらは小売店の $75.2 \%$ を占めていた，特に，衣 料品・身回品（靴, 鞄など）店の構成比が高く, そ れらは小売店の $37.0 \%$ をを占めていた. 一方, 最 寄品店では食料品店の構成比が高く, それらは小売 店の $19.7 \%$ を占めていた。

次に，旭センター街であるが，これは幅 4.5 $8 \mathrm{~m}$ の通りに面する商店街である.ここには, アー ケードは設置されていないが，モニュメントアーチ が 8 基設置されている. 以前, この通りは一般車両 の通行が禁止された歩行者専用であった，旭セン夕 一街には, 任意団体である商店会が組織されている.

旭センター街の発足は, 自然発生的であった.こ こには戦後まむなく, 飲食店や娛楽店の進出がみら れたが, その後 1984 年頃までに, 商店の集積が進 み, 商店街が形成されていった（相生市史編纂専門 委員会 1989: 919-944).

また, 旭センター街は, 播磨生活協同組合中央店 を核として発達してきた。これは, 1984 年に周辺 の土地を買収し, 店舗面積を拡大したが総合商品ス 


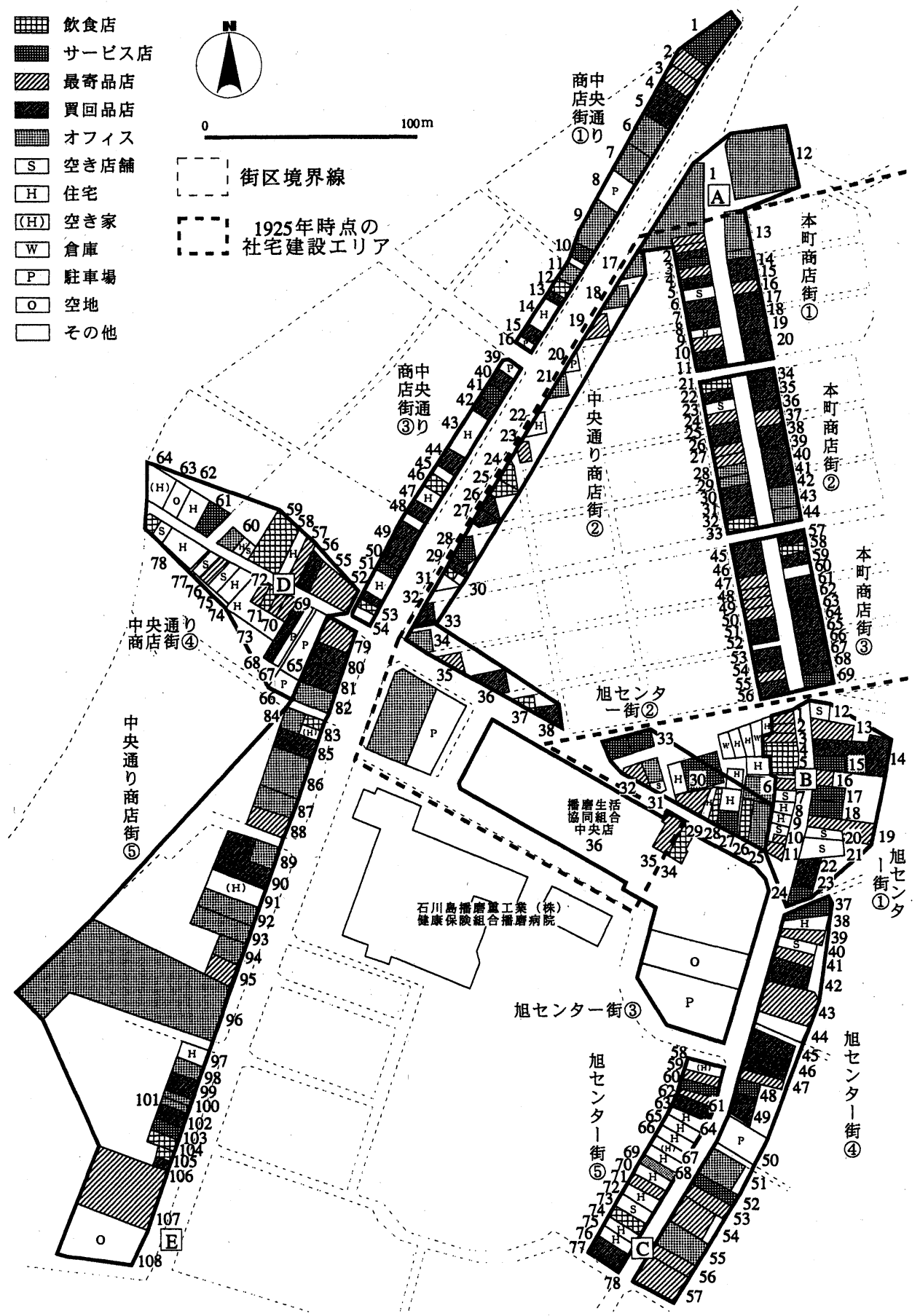

図 2 相生市の中心商業地の土地利用（1984 年）

$\mathrm{A}$ から $\mathrm{E}$ は, 歩行者通行量調査地点である。

(ゼンリン住宅地図および聞取り調查により作成)。

Fig. 2 Land use in the main shopping area in Aioi (1984) 
一パーとして中心商業地の核店舗となった（相生商 工会議所 1997：23).

旭センター街の特徴としては, 店舗と住宅と空き 店舗が混在していることが挙げられる（図 2)。店 舗密度が $62.0 \%$ であるのに対して, 商店街の総敷 地区画に占める住宅の割合は $16.5 \%$, 空き店舗の それは $10.1 \%$ であった。

また，旭センター街では，地区ごとに特徴が異な る. (1)地区は，本町商店街と播磨生協の間に立地し， 立地条件が良いにもかかわらず，空き店舗や住宅が みられた。(2)地区では，飲食店やサービス店の集積 がみられた。(4)地区では，小売店やサービス店の集 積がみられたが，他の地区と比べて店舗面積が大き い. (5)地区は元来 IHI の社宅であったため，住宅が 大半を占めていた.

旭センター街の 1984 年の店舗構成をみると, 小 売店が $71.4 \%$, 飲食店が $14.3 \%$, サービス店が $14.3 \%$ であった. 小売店のうち食料品店の構成比 が最も高く，それらは小売店の $30.6 \%$ を占めてい た。

最後に，中央通り商店街であるが，これは幅 10 $\mathrm{m}$ の都市計画道路の両側に展開している．歩道は 2 $\mathrm{m}$ であり，アーケードは設置されていない5)。車 道により分断されているため，両側はそれぞれ独立 したかたちで商業活動を展開している。ここには， 任意団体である商店会が組織されている.

この商店街の歴史は, 他の中心商店街と比べて浅 い. 1958 年に都市計画道路が完成し，その一部で ある中央通りは，市街地のメインストリートとなっ た. その後, 商店の集積が進み, 商店街が形成され ていった（相生商工会議所 1997：22）.

中央通り商店街の特徴としては, 市街地のメイン ストリートの両側に展開しているため, 店舗以外の オフィスの集積が進んでいたことが挙げられる（図 2). 店舗密度が $58.2 \%$ であるのに対し，オフィス が商店街の総敷地区画に占める割合は $16.4 \%$ であ
った。ささらに，通りが車道であるため，駐車場の利 用むみられた。一方, 空き店舗は少ないが，住宅が 多く, 商店街の総敷地区画の $12.5 \%$ を占めていた.

また，中央通り商店街では，地区ごとに特徴が異 なる。. (1)(2)(3)地区では，店舗や医療機関や製造業・ 建設業のオフィスの立地がみられた，中央通りに面 していない(4)地区では, 空き店埔や住宅が多くみら れた，(5)地区では，面積の大きい製造業・建設業の オフィスや店舗の立地もみられた。店舗面積が大き いのは，この地区が海を埋め立てて造成され，地元 企業をはじめとする有力な地主が広範囲に土地を所 有していたためである.

中央通り商店街の 1984 年の店舗構成をみると, 小売店が $70.3 \%$, 飲食店が $18.8 \%$, サービス店が 10. $9 \%$ であった. 小売店のうち食料品店の構成比 が最む高く，それらは小売店の $35.6 \%$ を占めてい た.

2） 2003 年の土地利用

1984 年から 2003 年にかけて, 中心商業地は IHI の合理化，郊外商業地の形成などの影響を受けた。 相生市全体で人口は減少しているが，中心商業地が 立地する旭地区では，その傾向が顕著である。1980 年から 2000 年にかけて, 市全体の人口減少率が 17. $3 \%$ であるのに対し，旭地区のそれは $19.5 \%$ と なっている6).

そのため, 中心商業地では, 歩行者通行量の減少 が著しい（表 2). 依然として, 本町商店街とコー プ周辺に通行量が集中している. 一方, 中央通り商 店街では通行量が少なく,さらに減少が著しい。ま た，いずれの調査地点においても，休日／平日の値 が低下しており, 中心商業地において, 特に休日の 集客力が弱まっているといえる.

このような周辺環境の変化に伴い, 2003 年の中 心商業地の土地利用 7) は, 1984 年と比較すると大 きく変化している(図3). 全体的には, 非商店化 の進展が顕著である，以下，商店街ごとに土地利用 
表 2 中心商業地における歩行者通行量の推移

Table 2 Changes in pedestrian traffic in the main shopping area

\begin{tabular}{|c|c|c|c|c|c|}
\hline 地点 & 指標 & 1983 & 1989 & 1995 & 2001 \\
\hline \multirow{4}{*}{ A } & 通行量（人） & 4,028 & 2,674 & 1,886 & 1,102 \\
\hline & 増減率（\%） & 100.0 & 66.4 & 46.8 & 27.4 \\
\hline & 休日／平日 & 0.83 & 0.69 & 2.38 & 0.54 \\
\hline & 最高地点に占める割合（\%） & 96.1 & 100.0 & 92.7 & 90.0 \\
\hline \multirow{4}{*}{ B } & 通行量（人） & 4,190 & 2,660 & 1,902 & 1,224 \\
\hline & 増減率（\%） & 100.0 & 63.5 & 45.4 & 29.2 \\
\hline & 休日／平日 & 0.85 & 0.76 & 0.68 & 0.59 \\
\hline & 最高地点に占める割合（\%) & 100.0 & 99.5 & 93.5 & 100.0 \\
\hline \multirow{4}{*}{ C } & 通行量（人） & 2,916 & 1,936 & 1,598 & 1,026 \\
\hline & 増減率（\%） & 100.0 & 66.4 & 54.8 & 35.2 \\
\hline & 休日 / 平日 & 0.78 & 0.65 & 0.60 & 0.58 \\
\hline & 最高地点に占める割合（\%） & 69.6 & 72.4 & 78.6 & 83.8 \\
\hline \multirow{4}{*}{ D } & 通行量（人） & 1,366 & 984 & 832 & 340 \\
\hline & 増減率（\%） & 0.67 & 0.49 & 0.41 & 0.17 \\
\hline & 休日／平日 & 0.51 & 0.34 & 0.69 & 0.52 \\
\hline & 最高地点に占める割合（\%) & 32.6 & 36.8 & 40.9 & 27.8 \\
\hline \multirow{4}{*}{$\mathrm{E}$} & 通行量（人） & - & - & 936 & 544 \\
\hline & 増減率 (\%) & - & - & 100.0 & 58.1 \\
\hline & 休日／平日 & - & - & 0.97 & 0.74 \\
\hline & 最高地点に占める割合（\%） & - & - & 46. 0 & 44.4 \\
\hline
\end{tabular}

各調査地点は図 2 に対応している.

一はデータなし。

(『相生市統計書』(相生市) 各年版により作成).

の変化を明らかにしていくことにする.

まず，本町商店街であるが，空き店舗の発生が顕 著である．空き店舗は，商店街の総敷地区画の $25.0 \%$ を占めている．特に，(1)地区では，面積の 大きい空き店舗屯みられ，さらに番号 17 から 20 の 建物にかけて連続して空き店舗が発生している，一 方， 1993 年以降の新規出店は， 3 店舗にとどまる. そのため, 店舗密度は低下し， $63.2 \%$ となってい る。また，駐車場はみられないが，今後番号 12 之 20 の建物は角地であるため，駐車場に転用される 予定である ${ }^{8)}$. 角地であれば一般車両の乗り入れが 禁止されている本町商店街においても，駐車場への 転用は可能である 9).

2003 年の店舗構成をみると，小売店が $90.7 \%$ を 占めている，小壳店のうち，依然として衣料品・身 回品店や食料品店の構成比は高く，それぞれ 39.5
\%，18.6\%となっている.

次に，旭センター街であるが，ここでは 1988 年 にカラー舗装とアーチが整備され，近代化が図られ た（相生商工会議所 1997：35)。さらに，1993 年 に播磨生協がコープこうべと合併し，コープデイズ 相生（以下，コープ）となった．コープは，店舗の 改装を行い，さらに立体駐車場を併設する形で開店 した（相生商工会議所 1997：43）.

近年，旭センター街では，このような整備がみら れ近代的な景観となっているが，非商店化が進展し ている．空き店舗や住宅は増加しており，それぞれ 商店街の総敷地区画の $17.7 \%, 22.8 \%$ を占めてい る。一方，店舗密度は大きく低下し， $40.5 \%$ とな っている。また，1997 年から一般車両の通行が許 可されたことああり，駐車場が角地以外にあみられ る．駐車場の多くは月極契約であり，番号 52 の敷 地のみが飲食店が設置した来客者用の駐車場である。 駐車場は, 商店街の総敷地区画の $7.6 \%$ を占めるに 至っている.

ここでは，地区ごとに土地利用の変化が大きく異 なる. (4)地区には，商業機能を伴わない中層マンシ ョンが立地しており，番号 47 と 57 の建物がそれに あたる，(1)地区では，立地条件が良いにあかかわら ず，さらなる空き店舗の発生がみられ，非商店が連 続している. しかし，(1)地区には，1993 年以降， 中心商業地の他の商店街から転入した店舗がみられ る.

2003 年の店舗構成をみると, 小売店が $68.8 \%$ を 占めている，小売店のうち，食料品店の構成比の低 下が著しく，21.9\% となっている.

最後に，中央通り商店街であるが，全体的に非商 店化が進展している．空き店舗，住宅，駐車場は増 加して打り，それぞれ商店街の総敷地区画の $24.3 \%$, 15. $9 \% ， 12.1 \%$ を占めている.一方, 店舗密度は 大きく低下し，29.9\% となっている．店舗が散在 しており，回遊性む低くなっている，そのためここ 


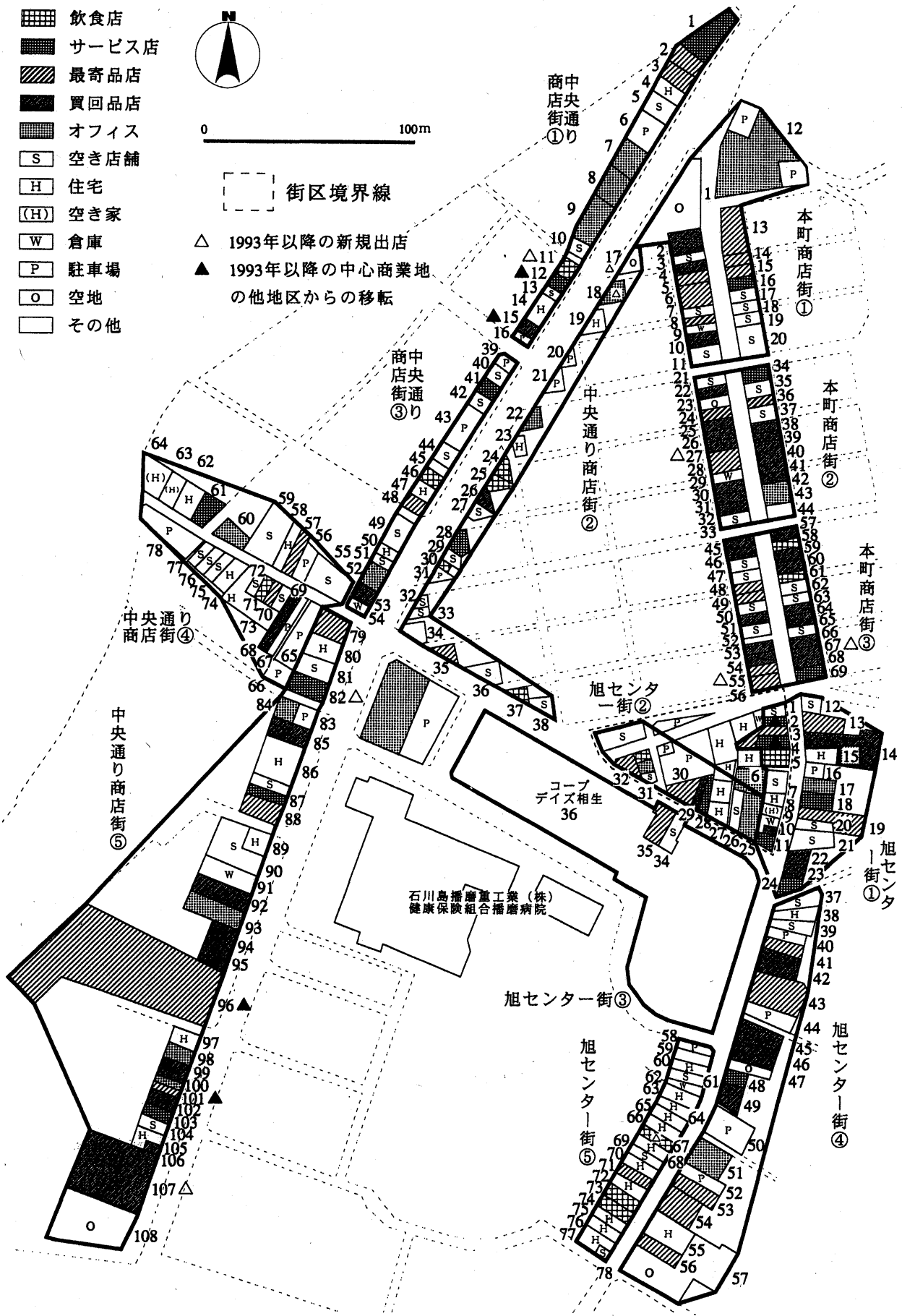

図 3 相生市の中心商業地の土地利用（2003 年） (ゼンリン住宅地図および聞取り調査により作成).

Fig. 3 Land use in the main shopping area in Aioi (2003) 


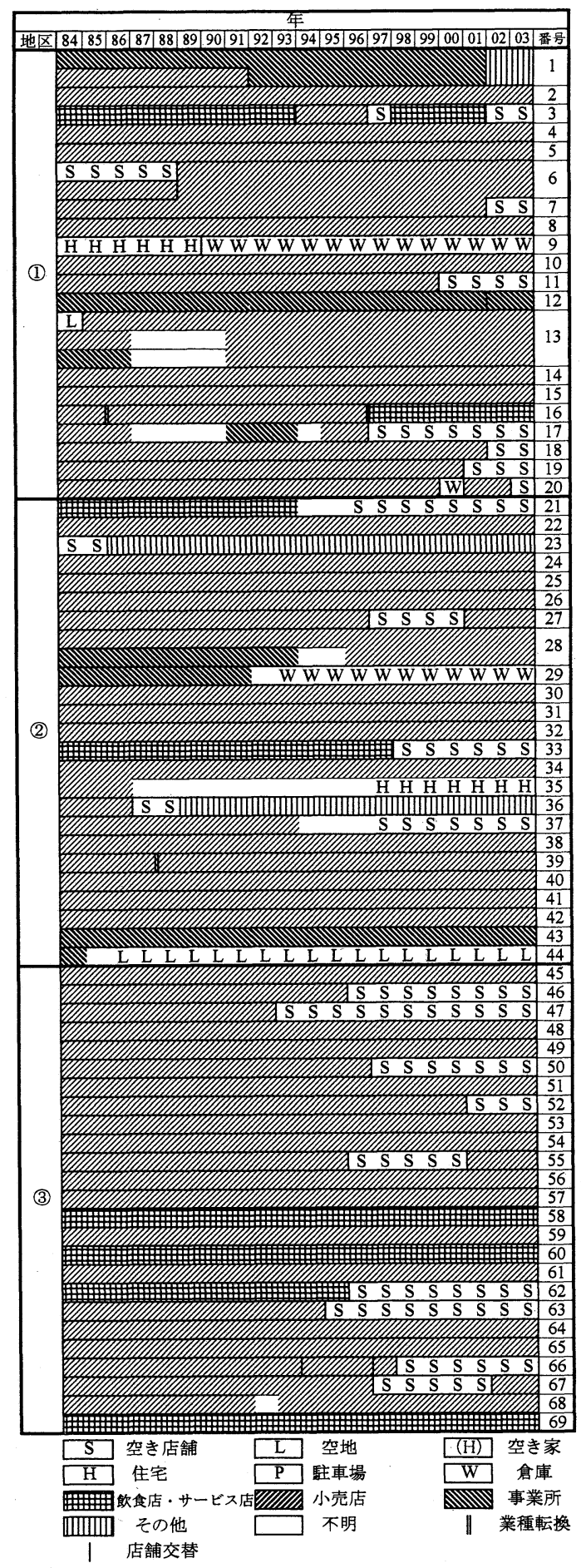

図 4 本町商店街における土地利用形態の変化 (聞取り調査により作成).

Fig. 4 Changes in land use in the Honmachi shopping district
こでは自動車などによる単一店舗への来店という購 買行動しか期待できず, 中央通り商店街は商店街と いう形態であるとは言い難くなっている，また，才 フィスは構成比を維持しており, それは商店街の総 敷地区画の $15.0 \%$ を占めている.

ここでは, 地区ごとに土地利用の変化が大きく異 なる. (4)地区では，以前から商業機能は弱かったが， さらにその状況に拍車がかかり, 数店舗が立地する のみである. (4)地区の衰退には, 食料品スーパー 55 が(5)地区の 96 へ移転したことが大きく関わって いる. 食料品スーパー 55 は, 1993 年に大型の駐車 場を確保し, 店舗面積を拡大するために移転した。 (5)地区は, 店埔の前に存在した幅 $5 \mathrm{~m}$ の排水路を 埋め立てたため, 歩道と合わせて $7 \mathrm{~m}$ 程度のスぺ 一スを店舗の前に確保している，そのため，各店舗 は駐車場を併設しなくても, 自動車での来店が可能 となっている，そのため，ここでは店舗密度が比較 的高い. 一方, (1)(2)(3)地区では, 各店舗が専用駐車 場を併設しない限り, 自動車での来店は不可能であ る。そのため,ここでは通り沿いに駐車場の立地が 進んでいる.

2003 年の店舗構成をみると, 飲食店とサービス 店の割合が，それぞれ $21.9 \% ， 25.0 \%$ に高まって いる.これらの構成比は, 他の中心商店街に比較す ると高い。一方，小売店の割合は低下している。 そ のうち，依然として食料品店の割合が高く，それは 小売店の $25.0 \%$ を占めている.

\section{2. 店舗交替からみた中心商業地の変容}

図 4 に, 1984 年から 2003 年までの本町商店街の 土地利用形態を経年的に示した。ここでは，店舗密 度が最も高く, 中心性の高い本町商店街について, 1984 年に営業が確認された 69 店舗（七つのオフィ スを含む）における店舗交替の状況を明らかにする. 1984 年から 2003 年にかけて， 36 店舗（52.2\%） では，店舗の交替がみられなかった。また，16 と 
39 では, 同一の経営者による業種転換がみられ， 現在でも営業が継続されている.

残りの 31 店舗（44.9\%）では，店舗が交替して いるか，店舗の閉鎖後新規出店がみられず，非商店 化している，店舗の交替が進み, 現在も営業が継続 されているのは 11 店舗ある. そのうち, 番号 1,6 , $13,28,68$ の建物は, 店舗の閉鎖後隣接店舗に買 収されている。また，番号 1 の区画には，近年運輸 業のオフィスの閉鎖後, 一時的に金融機関の仮設店 舗が立地している．番号 36 の建物は，店舗の閉鎖 後, コミュニティ施設 10) として利用されている. 一方, 店舗の交替が進んだものの, 現在非商店であ るのは 4 区画ある。また，店舗の交替が進まず，非 商店化したのは16 区画ある.

1984 年から 2003 年にかけて，延べ 39 区画にお いて，店舗の閉鎖がみられたが，その後の店舗交替 の状況はバブル経済崩壊前後で大きく異なる，バブ ル経済が崩壊する 1991 年以前では, 9 店舗の閉鎖 がみられたが，うち 7 店舗において隣接店舗による 買収か新規出店がみられ，非商店化したものは少な い. 一方, 1992 年以降では, 30 店舗の閉鎖がみら れたが，うち 13 店舗において新規出店がみられた のに対し，17 店舗では新規出店がみられず，空き 店舗化している。つまり, 企業城下町相生市におい て, 1980 年代の IHI 合理化により中心商業地は衰 退していたが, 1990 年代以降バブル経済の崩壊, 人口減少，郊外商業地の形成の影響を受け，さらに 衰退し，店舗の閉鎖が相次ぎ，それが新規出店を大 きく上回ったことになる．

また, 現在まで, 空き店舗が店舗として活用され ている区画では， 5 年以内に新規出店がみられてい る. 一方, 現在の空き店埔の中には, 6 年以上空き 店舗の状態のものが多く，空き店舗全体の $52.9 \%$ を占める. 空き店舗の長期化の要因として, 空き店 舗への新規参入需要が低下していることか, あしく は空き店舗の所有者の意向により店舗として活用さ
れていないことが考えられる.

\section{IV 中心商業地における非商店化の実態}

1. 中心商業地における店舗の閉鎖理由・形態

ここでは，2003 年時点での非商店における店舗 閉鎖の理由・形態を, 閉鎖前の店舗経営者の年齢, 店員数，資本関係などの店舗特性別に明らかにする。 つまり，どのような店舗が，どのような理由・形態 で店舗閉鎖に至るのかを明らかにする。

まず，表 3 に経営者の年齢別にみた店舗閉鎖理由 を示した. 本町商店街では, 60 歳以上の経営者の 店舗閉鎖の割合が高いが，閉鎖理由の多くは経営者 の死亡・高歯化である. 一方, 60 歳未満の経営者 の店舗では，営業不振による店舗閉鎖が多い，旭セ ンター街では，他の中心商店街ではあまりみられな い, 土地所有者の意向による店舗閉鎖がみられる。 つまり，ここではテナントによる営業がみられたが， 土地所有者がテナントを移転させ, 非商店に転用し たことになる. 中央通り商店街では, 60 歳以上の 経営者の店舗閉鎖の割合が $50.0 \%$ となっており, それらの閉鎖理由の大半は, 経営者の死亡・高齢化 である。

次に，店舗特性別にみた店舗閉鎖形態について明 らかにする。全体的には, 廃業・倒産の割合が高い (表 4). その割合は, 商店街別にみてもあまり変化 しない．店員数別にみると， 2 人以下の店舗が非商 店の総区画の $75.0 \%$ を占めており，これらは廃 業・倒産につながっている割合が高い，資本関係別 にみると, 単独店が非商店の総区画の $69.4 \%$ を占 めているが，これらも廃業・倒産につながっている 割合が高い，一方，支店では，撤退・移転の割合が 高く, 66. 7\% となっている. 店舗の閉鎖理由別に みると, 経営者の死亡・高齢化が最も多く, $45.3 \%$ を占めているが，これらは廃業・倒産につながって いる割合が高い.

以上のような理由・形態により店舗は閉鎖してい 
表 32003 年時点での非商店における経営者の年齢別にみた店舗閉鎖 理由

Table 3 Reasons for store closures based on age of managers in nonretail spaces, 2003

単位: 店

\begin{tabular}{|c|c|c|c|c|c|}
\hline & \multicolumn{4}{|c|}{ 店舗閉鎖時における経営者の年齢 } \\
\hline & & 40 歳未満 & $\begin{array}{l}40 \text { 歳以上 } \\
60 \text { 歳未満 }\end{array}$ & 60 歳以上 & 計 \\
\hline \multicolumn{2}{|r|}{ 全体 } & 7 & 21 & 26 & 54 \\
\hline \multirow[t]{2}{*}{ 本町商店街 } & $\begin{array}{l}\text { 経営者の死亡・高齢化 } \\
\text { 営業不振 } \\
\text { 土地所有者の意向 } \\
\text { 経営規模の縮小 } \\
\text { その他. }\end{array}$ & 2 & $\begin{array}{l}1 \\
4\end{array}$ & $\begin{array}{l}6 \\
1 \\
1 \\
2\end{array}$ & $\begin{array}{l}7 \\
7 \\
1 \\
2 \\
1\end{array}$ \\
\hline & 計 & 2 & 6 & 10 & 18 \\
\hline \multirow[t]{2}{*}{ 旭センター街 } & $\begin{array}{l}\text { 経営者の死亡·高齢化 } \\
\text { 営業不振 } \\
\text { 土地所有者の意向 } \\
\text { 経営規模の縮小 } \\
\text { その他 }\end{array}$ & $\begin{array}{l}1 \\
1\end{array}$ & $\begin{array}{l}1 \\
3 \\
1\end{array}$ & $\begin{array}{l}2 \\
1 \\
2 \\
2\end{array}$ & $\begin{array}{l}3 \\
3 \\
3 \\
1 \\
4\end{array}$ \\
\hline & 計 & 4 & 5 & 5 & 14 \\
\hline \multirow[t]{2}{*}{ 中央通り商店街 } & $\begin{array}{l}\text { 経営者の死亡・高齢化 } \\
\text { 営業不振 } \\
\text { 土地所有者の意向 } \\
\text { 経営規模の縮小 } \\
\text { その他 } \\
\end{array}$ & 1 & $\begin{array}{l}5 \\
1\end{array}$ & $\begin{array}{r}10 \\
1\end{array}$ & $\begin{array}{r}15 \\
3 \\
4 \\
4\end{array}$ \\
\hline & 計 & 1 & 10 & 11 & 22 \\
\hline
\end{tabular}

店舗閉鎖理由および経営者の年歯が不明な非商店を除く.

(聞取り調査により作成).

る. 最む多いのは, 店員数の少ない単独店が経営者 の死亡・高齢化，営業不振に伴い廃業し，店舗閉鎖 している事例である.

2. 中心商業地に㧍ける非商店化の過程と要因 店舗閉鎖後の非商店は，大きく空き店舗，住宅・ マンション，駐車場に分けることができる．ここで は，非商店の種類之店舗特性や店舗閉鎖理由との関 係を明らかにする。つまり，どのような店舗が，ど のようなかたちで，さらになぜ空き店舗や住宅や駐 車場に変化するのかを明らかにする。

表 5 に, 非商店の種類別にみた閉鎖前の店舗経営 者の居住地や所有者の属性などの店舗特性を示した. 全体的に非商店の種類としては，空き店舗が多いが，
その約半数に住民が存在している.

店舗閉鎖以前の経営者の居住地についてみると, 店舗が最む多く，その場合住民のいる空き店舗とな っている割合が高い，一方，経営者の居住地が店舗 から離れると，住民のいない空き店舗になっている 割合が高い。

店舗閉鎖以前の所有者の居住地についてみると， 店舗の場合，住民のいる空き店舗汃住宅になってい る割合が高い。所有者の居住地が店舗から離れると， 住民のいない空き店舗か駐車場になっている割合が 高い.

所有者の属性と経営者との関係についてみると， 個人の所有者が多いが，経営者之同一の場合，住民 のいる空き店舗になっている割合が高い，経営者と 
表 4 店舗特性からみた店舗閉鎖形態

Table 4 Forms of store closure based on store characteristics

\begin{tabular}{|c|c|c|c|c|c|}
\hline & & \multirow{2}{*}{ 区画数 } & \multicolumn{3}{|c|}{ 店舗閉鎖形態 } \\
\hline & & & 廃業・倒産 & 撤退・移転 & 休業中 \\
\hline \multicolumn{2}{|r|}{ 全体 } & 64 & 59.4 & 35.9 & 4.7 \\
\hline \multirow{3}{*}{ 所属商店街 } & 本町商店街 & 21 & 57.1 & 38.1 & 4.8 \\
\hline & 旭センター街 & 16 & 62.5 & 31.3 & 6.3 \\
\hline & 中央通り商店街 & 27 & 59.3 & 37.0 & 3.7 \\
\hline \multirow{3}{*}{ 店員数 } & 2 人以下 & 39 & 66.7 & 28.2 & 5.1 \\
\hline & 3 人以上 5 人以下 & 10 & 60.0 & 30.0 & 10.0 \\
\hline & 6 人以上 & 3 & 66.7 & 33.3 & 0.0 \\
\hline \multirow{3}{*}{ 資本関係 } & 単独店 & 43 & 79.1 & 18.6 & 2.3 \\
\hline & 本店 & 4 & 25.0 & 75.0 & 0.0 \\
\hline & 支店 & 15 & 20.0 & 66.7 & 13.3 \\
\hline \multirow{5}{*}{ 店舗閉鎖理由 } & 経営者の死亡・高齢化 & 24 & 83.3 & 12.5 & 4.2 \\
\hline & 営業不振 & 13 & 84.6 & 15.4 & 0.0 \\
\hline & 土地所有者の意向 & 5 & 40.0 & 60.0 & 0.0 \\
\hline & 経営規模の縮小 & 3 & 66.7 & 0.0 & 33.3 \\
\hline & その他 & 8 & 50.0 & 50.0 & 0.0 \\
\hline
\end{tabular}

店員数，資本関係ならびに店舗閉鎖理由が不明な非商店を除く.

(聞取り調査により作成).

表 5 非商店の種類別にみた店舗特性

Table $5 \quad$ Store characteristics by type of nonretail use

\begin{tabular}{|c|c|c|c|c|c|c|c|}
\hline & & \multirow{2}{*}{ 区画数 } & \multicolumn{2}{|c|}{ 空き店舗 } & \multirow{2}{*}{$\begin{array}{l}\text { 住宅・マ } \\
\text { ンション }\end{array}$} & \multirow{2}{*}{ 駐車場 } & \multirow{2}{*}{ その他 } \\
\hline & & & 住民有 & 住民無 & & & \\
\hline \multicolumn{2}{|r|}{ 全体 } & 64 & 32.8 & 28.1 & 17.2 & 12.5 & 9.4 \\
\hline \multirow{3}{*}{ 経営者の居住地 } & 店舗 & 29 & 44. 8 & 10.3 & 27.6 & 13.8 & 3.4 \\
\hline & 中心部内 & 9 & 22.2 & 33.3 & 11.1 & 33.3 & 0.0 \\
\hline & 中心部外 & 15 & 20.0 & 53.3 & 0.0 & 20.0 & 6.7 \\
\hline \multirow{3}{*}{ 所有者の居住地 } & 店舗 & 20 & 40.0 & 10.0 & 50.0 & 0.0 & 0.0 \\
\hline & 中心部内 & 14 & 14.3 & 42.9 & 0.0 & 21.4 & 21.4 \\
\hline & 中心部外 & 16 & 12.5 & 50.0 & 0.0 & 25.0 & 12.5 \\
\hline \multirow{4}{*}{$\begin{array}{l}\text { 所有者の属性と } \\
\text { 経営者との関係 }\end{array}$} & 個人 (同一) & 26 & 46.2 & 23.1 & 23.1 & 0.0 & 7.7 \\
\hline & 個人 (別) & 20 & 30.0 & 30.0 & 20.0 & 20.0 & 0.0 \\
\hline & 法人 (同一) & 4 & 50.0 & 25.0 & 0.0 & 25.0 & 0.0 \\
\hline & 法人 (別) & 12 & 8.3 & 33.3 & 8.3 & 25.0 & 25.0 \\
\hline \multirow{5}{*}{ 店舗閉鎖理由 } & 経営者の死亡 · 高齢化 & 25 & 44.0 & 20.0 & 24.0 & 8.0 & 4.0 \\
\hline & 営業不振 ‘ & 13 & 38.5 & 46.2 & 0.0 & 0.0 & 15.4 \\
\hline & 土地所有者の意向 & 5 & 0.0 & 20.0 & 60.0 & 20.0 & 0.0 \\
\hline & 経営規模の縮小 & 1 & 0.0 & 100.0 & 0.0 & 0.0 & 0.0 \\
\hline & その他 & 12 & 41.7 & 8.3 & 0.0 & 41.7 & 8.3 \\
\hline
\end{tabular}

経営者の居住地, 所有者の居住地, 所有者の属性と経営者の関係ならびに店舗閉鎖理由が不明な 非商店を除く。

(聞取り調查により作成). 
表 6 住民の有無別にみた空き店舗の賃 貸の可能性

Table 6 Possibility of lease of vacant stores by the presence of residents

\begin{tabular}{|c|c|c|c|c|}
\hline t. & & 区画数 & 住民有 & 住民無 \\
\hline \multicolumn{2}{|l|}{ 全体 } & 39 & 53.8 & 46.2 \\
\hline \multirow{3}{*}{ 賃貸の可能性 } & 可 & 15 & 33.3 & 66.7 \\
\hline & 否 & 13 & 76.9 & 23.1 \\
\hline & 不明 & 11 & 54.5 & 45.5 \\
\hline
\end{tabular}

別の場合は, 空き店舗になっている割合が高いが, 住宅・マンションや駐車場にもなっている。これら は，所有者がテナントに賃貸していたが，店舗の閉 鎖後，テナントを再び入居させることなく，住宅や 駐車場に転用しているためである．所有者が法人の 場合は, 経営者と別であることが多く, 空き店舗だ けでなく，駐車場や住宅にあなっている.

店舗閉鎖理由についてみると, 経営者の死亡・高 齢化により閉鎖した店舗は，住民のいる空き店舗に なっている割合が高い。また，営業不振により閉鎖 した店舗では，空き店舗になっている割合が高い， 土地所有者の意向により閉鎖した店舗では，住宅・ マンションや駐車場になっている割合が高い.

以上をまとめると，以下のようになる．経営者や 所有者が店舗に居住していた場合，店舗の閉鎖後， 住民のいる空き店舗か住宅になっている割合が高い. 一方, 経営者や所有者の居住地が店舗から離れると, 住民のいない空き店埔や駐車場や住宅になっている 割合が高い。また, 個人所有で経営者と所有者が同 じである場合, 空き店舗や住宅になっている。一方, 経営者と所有者が別の場合や法人が所有している場 合，駐車場になっている割合も高い。

また, 表 6 に示したように, 賃貸の可能性が低い, つまり所有者に賃貸の意思のない空き店舗が，空き 店舗全体の 3 分の 1 を占めている，特に，住民のい る空き店舗では, 賃貸可能性の低い空き店舗の割合
が高い，したがって，空き店舗における住民の存在 が, 店舗交替を阻害している一つの要因であるとい える，賃貸の可能性が不明である区画を除くと，約 半数の空き店舗は賃貸の可能性がある. しかし, 店 舗として活用されていない状況から考えると，相生 市の中心商業地への新規参入需要が弱まっていると いえる.

一方，空き店舗に住民がいない場合には，賃貸の 可能性が高い. しかし, 所有者の居住地が店舗から 離れている場合屯あり，店舗としての活用に消極的 な所有者むみられ, 店舗の老朽化が懸念される。さ らに, 所有者が空き店舗の維持管理を効率化し, 駐 車場や住宅に転用している事例むみられる，店舗閉 鎖後に住宅や駐車場に転用されると, 再び店舗とし て活用されるとは考えにくい，つまり，住宅や駐車 場への転用も，店舗交替の阻害要因である。しかし， 店舗としての活用に消極的な所有者が存在すること は, 新規参入需要が弱まっている, つまり中心商業 地がかつての商業規模・エリアを必要としなくなり 縮小していることが背景にあるためであろう.

\section{V おわりに}

本研究では, 企業城下町相生市を事例に, 企業の 合理化に伴う中心商業地の変容を明らかにするため に, 店舗交替の経年的変化と非商店の実態から非商 店化の過程と要因を解明した。 その結果, 以下のこ とが明らかになった。

相生市を取り巻く状況は, 1986 年の IHI 合理化 以降，産業構造を転換することができず，人口減少 に歯止めがかからないため, 現在む厳しい，そのた め, 商業環境屯隣接市と比較すると, 衰退が早くか ら顕在化するとともに，近年その程度は深刻化して いる.

こうした状況において, 中心商業地の土地利用は 大きく変化している，また，中心商業地が立地する 地区の人口は，著しく減少している，そのため，歩 
行者通行量屯減少しており, 非商店化が進展してい る.

土地利用の变化は, 中心商店街ごとに大きく異な る. まず, 本町商店街は, 戦前企業の労働者とその 家族のために設立された売店組合を基盤として, 戦 後発達し, 中心商業地で最む中心性の高い商店街と なった。しかし，近年空き店舗が増加しており，店 舗密度は低くなっている，次に，旭センター街は， 戦後から 1980 年代にかけて店舗の集積が進み, 形 成された商店街であり, 大型店を核に発達してきた. しかし，近年，一般車両の通行が許可されたことも あり, 空き店舗の増加とともに駐車場や住宅やマン ションへの転用がみられ, 店舗密度は大きく低下し ている. 最後に, 中央通り商店街は, 車道の整備に 伴う店舗の集積により形成された商店街であり，中 心商業地で最む歴史が浅い。ここでは, 従来からオ フィスが多く立地しており, 店舗密度は以前から他 の中心商業地より低かった。しかし，近年空き店舗 が急増するとともに，駐車場や住宅への転用もみら 机、そのため, 店舗密度は著しく低下し，モー夕 リゼーションに対応できている店舗が散在している にすぎない。

中心商業地における店舗交替の状況は，バブル経 済崩壊前後で大きく異なる。 バブル経済崩壊以前は, 店舗交替が進展していたが，崩壊後新規出店は少な く，店舗閉鎖が非商店化につながっている。つまり， 企業城下町相生市において, 1980 年代の IHI 合理 化により中心商業地は衰退していたが，1990 年代 以降バブル経済の崩壊，人口減少，郊外商業地の形 成の影響を受け，さらに衰退し，店舗の閉鎖が相次 ぎ，それが新規出店を大きく上回ったことになる.

中心商業地における店舗の閉鎖理由・形態ならび に非商店化の過程と要因は, 店舗特性によって大き く異なる，特に多いのは，店員数の少ない単独店が, 経営者の死亡’・高齢化, 営業不振に伴い廃業し閉鎖 している事例である．閉鎖前に経営者が店舗に居住
していた場合は，閉鎖後も住民のいる空き店舗にな っている割合が高い，住民のいる空き店舗は，賃貸 の可能性が低く, 店舗交替の進展を阻害している. 一方，空き店舗に住民がいない場合む，所有者の居 住地が店舗から離れている区画では，店舗としての 活用に消極的な所有者屯存在し，店舗の老朽化が懸 念される.さらに, 空き店舗の維持管理を効率化し, 駐車場や住宅にしている所有者む存在する。住宅や 駐車場になると，再び店舗として活用されにくい， したがって，駐車場や住宅への転用も，店埔交替を 阻害しているといえる. しかし, 賃貸可能性のある 空き店舗が未活用であったり, 店舗としての活用に 消極的な所有者が存在したりすることから，新規参 入需要の低下が店舗交替を阻害している主たる要因 であるといえる。

以上をまとめると, 本研究の結果として, 以下の 結論を導くことができる. 企業城下町相生市の中心 商業地は, 企業の発展ととあに発達し, 従業員や近 隣住民に物資やサービスを供給する役割を担ってき た．中心商業地は，売店組合から発展した本町商店 街を核に, 戦後から 1980 年代にかけてェリアを拡 大していった. しかし，相生市では 1980 年代の企 業合理化後, 産業構造の転換を図ることができず, 人口は著しく減少した。ささに，1990 年代にはバ ブル経済の崩壊, 郊外商業地の形成により, 中心商 業地の地位は低下した。そのため, 居住人口の減少 とともに, 歩行者通行量も減少したため, 店舗の閉 鎖が相次いだ。 バブル経済崩壊以前は，店舗の交替 が進展していたが, 崩壊後は新規出店がみられず, 店舗の閉鎖が非商店化につながっている. 非商店の 中には，居住者の存在により賃貸の可能性の低い空 き店舗や, 所有者の意向により転用された住宅や駐 車場も含まれ，店舗交替が阻害されている区画も存 在する. しかし, 賃貸可能性のある空き店舗が未活 用であることから, 店舗交替を最む阻害している主 たる要因は, 新規参入需要の低下である。つまり, 
主要企業の合理化により衰退しつつあった中心商業 地において, バブル経済崩壊, 郊外商業地の形成に より新規参入需要が低下し, 非商店化しているとい える.したがって, 企業城下町の中心商業地におけ る非商店化は, 中心商業地の商業規模・エリアの縮 小を示しているのである.

今後, 企業城下町の中心商業地は新たな役割を担 わなくてはならない，そこでは，従来型の店舗だけ ではなく，新業態の店舗やコミュニティ施設などむ 必要となるであろう。そのために, 空き店舗を活用 するのあ一つの手段である.こうしたことが，企業 城下町の中心商業地には求められるが，空き店舗対 策を含む活性化の方向性や取組みへの評価は今後の 研究課題としたい.

本稿は, 2002 年度に岡山大学大学院自然科学研究科 へ提出した修士論文に加筆修正を加えたすのである，本 稿を作成するにあたり，終始御指導をいただいた岡山大 学の北村修二先生, 金 枓哲先生をはじめとする岡山大 学環境理工学部環境経営学講座の教員の皆様に厚くお礼 を申し上げます．また，調查に御協力をいただいた相生 市役所, 商工会議所, 振興組合・商店会の理事の皆様に は, 資料の提供をはじめ, 長時間の聞取り調査に御協力 いただきました。 また, 商店街の構成店舗の皆様にも, 聞取り調査に御協力いただき, 貴重な各店舗の状況を収 集することができました，さらに，研究室の後輩達には 終始アドバイスをいただいた，これらの方々にも，厚く お礼を申し上げます。なお，本稿の骨子は 2002 年度地 域地理科学会例会にて発表した.

（投稿 2005 年 7 月 25 日）
(受理 2006 年 3 月 4 日)

\section{注}

1）本研究では，店舗の閉鎖後 1 年以上新規出店がみられ ず，店舗として活用されていない状態を非商店と定義す る. 一方, 店舗之は, 小売店に飲食店, サービス店を加 えたすのとする.

2）本研究において，住宅とは店舗形態を保持しないあの とし, 住民の存在があり店舗形態を保持している空き店 舗とは区別する．非商店化としての住宅への転用とは, 建物を建て替えた場合に限ることにする。

3） 2002 年 10 月から 2003 年 1 月にかけて中心商店街の 振興組合ならびに商店会の理事長に対して行った。一部,
補足的に空き店舗の居住者や空き店埔近隣の商業者に聞 取り調查を行った。調查対象は, 本通り商店街では全地 区の非商店 (21 区画), 旭センター街については, 商業 集積があまりみられない(2)(3)(5)地区を除いた(1)(4)地区の 非商店 (16区画), 中央通り商店街では同様に(2)(4)地区 を除いた(1)(3)(5)地区の非商店（27区画）を対象とした (1)〜(5)については図 2 参照)。調查は, 記入式ではなく, 対面式で行った.

4）播磨船渠株式会社（後の株式会社播磨造船所）は, 当 時の相生村長が地元の有力者や神戸の財界に協力を呼び かけて相生港の対岸に船の修理ドックを整備し，1908 年に設立された。そして，1960 年に石川島重工業と合 併し, 石川島播磨重工業之なった（相生商工会議所 1997: 1-10).

5）以前, 中央通り商店街では, アーケードの設置も検討 されたが, 商業機能, 居住機能, 業務機能が混在してい るため，実現には至らなかった。

6)『相生市統計書』(相生市) 各年版より算出.

7） 2003 年の土地利用は, 2 月の状況である.

8）番号 12 の敷地には, 2003 年時点で金融機関の建替え 工事による仮設店舗が立地しているが, その後駐車場に 転用されることになっている. 番号 20 の建物は, 2003 年時点では空き店舗であったが，5階建てであるため固 定資産税が高く, 土地所有者が駐車場への転用を決定し た（振興組合の理事長に対する聞取り調査による）。

9）振興組合によるアンケート調查（2000 年 10 月 4 日） では, 一般車両の進入について, 条件付きで賛成が 23 店舗, 反対 13 店舗, その他 4 店舗であり, 一般車輌の 通行希望が過半数を占める. 一般車両の通行が許可され た場合, 角地に立地しない店舗でも駐車場への転用が可 能となり, 土地所有者の意志決定によっては駐車場が増 加していく可能性むある. 事実一部の所有者は駐車場へ の転用を希望している.

10） 1989 年に設置された本町カルチャーセンターである. 当時, 店舗の閉鎖に危機感を持った振興組合が店舗を買 収し整備した，施設のスペースを市民に有料で貸し出し ており, 毎週日曜日に NPO が朝市を開くなど市民や団 体の活動が展開されている.

\section{文 献}

相生市史編纂専門委員会 1989. 『相生市史第三巻』. 相生 市・相生市教育委員会.

相生商工会議所 1997. 『相生市商工会議所創立 50 周年記 念誌』相生商工会議所.

五十嵐 篤 1996. 富山市における中心商店街の構造変化 一一経営者意識との関連性を含めて。 人文地理 48: 468 $-481$.

石澤 孝 1999. 長野に㧍ける中心商店街の变容に関する 
ノート—ーポストオリンピックにおける長野を考えるた めに. 信州大学教育学部紀要 96: 35-46.

川田力 1999. 岡山市中心市街地における商業停滞地区 の現状一一岡山市奉還町商店街を中心として. 岡山大学 教育学部研究集録 111：65-74.

兼子 純 - 山下亜紀郎・豊島健一・高橋珠州彦・ 川瀬正 樹・高橋伸夫 2002 . 水戸市中心市街地における商業地 域構造と地域活性化. 地域調査報告 24：1-31.

国立国会図書館調査立法考査局 1990。 『〈総合実態調査報 告〉産業構造の調整と地域問題——“企業城下町” 相生 市の場合』国立国会図書館調査立法考查局.
杉村暢二 1998.『中心商業地の変容』大明堂.

千葉昭彦 1999. 郊外大型店の成立と商店街のまちづくり 一一鶴岡市・白河市を検討事例として. 東北産業経済研 究所紀要 18: 83-100.

戸所 隆 1991. 『商業近代化と都市』古今書院.

根田克彦 1999.『都市小売業の空間分析』大明堂.

林上 2001. 岐阜県土岐市における伝統的商業地区の 衰退とその対策. 情報文化研究 13：37-63.

マックスバリュ西日本株式会社 2002.2002 年 ・上期の二 ユース. http : //www. maxvalu. co. jp/main/index. html（最終閲覽日：2006 年 1 月 20 日） 


\section{Transformation of the Main Shopping Area in a Company Town by Rationalization of the local dominant Enterprise: The Case of Aioi, Hyogo Prefecture, Japan}

NANIWADA Takao (Foundation for Environmental Rehabilitation and Redevelopment of Mizushima)

In this research, the case of the company town Aioi was investigated to clarify the transformation of the main shopping area by rationalization of the local dominant enterprise, namely Ishikawajima-Harima Heavy Industries Co., Ltd. In addition, the process and factors leading to changes in use such as vacant stores, parking lots, or residences were clarified along with the status of closed stores.

The situation in Aioi remains difficult because the industrial structure has not been converted and the population has continuously decreased since the rationalization of the enterprise. Therefore, the commercial environment has declined markedly.

The decrease in the population and the amount of pedestrian traffic has been significant, and the land use has changed greatly in the main shopping area. Changes to nonretail use are progressing in general, while changes in land use differ greatly in each shopping district. Changes to nonretail use did not occur before the collapse of the bubble economy because alterations in retail stores continued. However, store closures have been correlated with changes to nonretail use since the collapse of the bubble economy because few new businesses have opened.

The reasons for and the forms and processes of store closures in the main shopping area differ greatly depending on store characteristics. Many stores closed due to personal circumstances or slumps in business in small-scale stores.

Among closed stores, there are many vacant stores with little possibility of retail rental, since there are residents now. In addition, some were converted into residences and parking lots by their owners. These factors prevent alterations in previous stores to new retail use. However, the main factor preventing new retail use is the decrease in new entry demand.

Although the main shopping area was declining because of rationalization of the enterprise in the 1980s, changes to nonretail use have continued because new entry demand has decreased due to the collapse of the bubble economy, population decrease, and the development of shopping areas in the suburbs after the $1990 \mathrm{~s}$. Therefore, the changes to nonretail use in the main shopping area in this company town reflect a reduction in commercial scale and area.

Key words: vacant store, main shopping area, company town, rationalization of the local dominant enterprise, Aioi, Hyogo prefecture 